\title{
MENINGKATKAN KEMAMPUAN MENULIS PARAGRAF PERSUASIF MELALUI POLA LATIHAN BERJENJANG
}

\author{
ENHANCEMENT OFTHE STUDENTS ABILITY IN COMPOSING \\ PERSUASIVE PARAGRAPHTHROUGH 'LEARNINGBY STAGE METHOD'
}

\author{
Abdullah \\ SMA Negeri 1 Praya \\ Tanggal naskah masuk: 27 September 2012 \\ Tanggal revisi terakhir: 22 November 2012
}

\begin{abstract}
Most students perceive that writing skill is a difficult subject. This problem is shown by the result of their writing test. What they write are not merely the expression of their idea, opinion and interest. The test also shows the lack in the usage of punctuation, spelling, choice of words, and sentence structure. Moreover, they do not know how to compose persuasive paragraph in appropriate structure. Such result means that the students still do not compose paragraph in effective way. A solution suggested for that problem is by implementing what is called 'Learning by Stage Method'. Through this method, students are required to write stage by stage; that is, from spelling stage to paragraph stage and from simple to complex. By implementing this method, significant increase is obtained in every stage of learning. In the first stage, the result of test reaches $67 \%$ and increase up to $88.24 \%$ in the second stage. In the third stage, the result reaches 91.18\%. It can be concluded that the implementation of 'Learning by Stage Method' contributes to the improvement of the students' skill in composing persuasive paragraph.
\end{abstract}

Keywords: compose, persuasive, learning by stage

\begin{abstract}
Abstrak
Keterampilan menulis merupakan aktivitas pembelajaran yang dianggap sulit oleh siswa. Permasalahan ini tampak pada hasil tulisan siswa yang tidak sepenuhnya mencerminkan ide atau gagasan yang dipikirkan. Apa yang ditulis sering tidak menunjukkan apa yang diinginkan. Hal ini membuktikan bahwa siswa yang bersangkutan belum menulis secara efektif. Ketidakefektifan tulisan tersebut disebabkan oleh tidak jelasnya penggunaan tanda baca, ejaan, pilihan kata, dan struktur kalimat yang masih rancu. Permasalahan tersebut ditambah lagi dengan belum dipahaminya struktur tulisan persuasif yang harus dibuat. Salah satu solusi yang diterapkan untuk mengatasi permasalahan tersebut adalah dengan pola latihan berjenjang. Pola latihan berjenjang melatih siswa menulis secara bertahap, mulai dari tataran ejaan sampai wacana, mulai dari yang sederhana menuju yang lebih kompleks. Penerapan pola ini menunjukkan peningkatan hasil belajar siswa pada setiap siklus. Hasil belajar pada siklus I mencapai $61,76 \%$. Pada siklus II meningkat menjadi $88,24 \%$ dan pada siklus III meningkat lagi menjadi $91,18 \%$. Dengan demikian, dapat disimpulkan bahwa pola latihan berjenjang mampu meningkatkan kemampuan siswa dalam menulis paragraf persuasif.
\end{abstract}

Kata kunci: menulis, persuasif, latihan berjenjang 


\section{Pendahuluan}

Mata pelajaran bahasa Indonesia bertujuan agar peserta didik memiliki kemampuan, antara lain berkomunikasi secara efektif dan efisien sesuai dengan etika yang berlaku, baik secara lisan maupun tulis (Permendiknas) ${ }^{1}$. Untuk itu, ruang lingkup mata pelajaran bahasa Indonesia mencakup komponen kemampuan berbahasa dan kemampuan bersastra yang melingkupi aspek-aspek mendengar, berbicara, membaca, dan menulis. Mendengar dan membaca dikategorikan sebagai keterampilan yang apresiatif reseptif, sedangkan berbicara dan menulis dikategorikan sebagai keterampilan produktif ekspresif.

Menulis merupakan suatu kegiatan yang produktif dan ekspresif. Dalam kegiatan menulis ini maka sang penulis haruslah terampil memanfaatkan grafologi, struktur bahasa, dan kosa kata. Keterampilan menulis ini tidak akan datang secara otomatis, melainkan harus melalui latihan dan praktik yang banyak dan teratur (Tarigan) ${ }^{2}$.

Berdasarkan hasil latihan menulis siswa dan diskusi dengan guruguru bahasa Indonesia, ternyata keterampilan menulis merupakan salah satu keterampilan berbahasa yang dianggap siswa sebagai aktivitas pembelajaran yang sulit. Siswa sering merasa kesulitan menuangkan ide-ide atau pikirannya ke dalam bentuk tulisan. Ketika diberikan tugas untuk menulis, siswa sering tidak tahu apa yang akan ditulis dan tidak memahami bagaimana memulai sebuah tulisan. Namun demikian, karena menulis merupakan sebuah keharusan, kegiatan tersebut harus dijalani siswa dengan hasil yang belum sepenuhnya memenuhi harapan. Pembelajaran menulis paragraf, baik paragraf deskripsi, narasi, eksposisi, argumentasi, dan persuasi yang telah dilakukan menunjukkan bahwa siswa kelas X-4 SMA Negeri 1 Praya mengalami kesulitan dalam menuangkan pikiran-pikirannya dalam bentuk tulisan. Apa yang ditulis sering tidak menunjukkan apa yang dipikirkan. Hal ini membuktikan bahwa siswa yang bersangkutan belum menulis secara efektif. Ketidakefektifan tulisan tersebut disebabkan oleh tidak jelasnya penggunaan tanda baca, ejaan, pilihan kata, dan struktur kalimat yang masih rancu. Tarigan $^{3}$ menyatakan bahwa tulisan yang baik mencerminkan kemampuan sang penulis untuk 
menulis dengan jelas dan tidak samar-samar: memanfaatkan struktur kalimat, bahasa, dan contoh-contoh sehingga maknanya sesuai dengan yang diinginkan oleh sang penulis.

Tentu saja kekurangan yang dialami siswa bukanlah sematamata kelemahan siswa. Tarigan ${ }^{4}$ juga mengatakan pengajaran mengarang belum terlaksana dengan baik di sekolah. Kelemahannya terletak pada cara guru mengajar. Umumnya kurang pada variasi, tidak merangsang dan kurang pula dalam frekuensi. Pembahasan karangan siswa kurang dilaksanakan oleh guru. Murid sendiri menganggap mengarang tidak penting atau belum mengetahui peranan mengarang bagi kelanjutan studi mereka.

Sementara itu, pada pembelajaran menulis paragraf khususnya paragraf persuasi, guru sering menugasi siswa menulis paragraf setelah ditentukan topiknya. Guru sering lupa bahwa paragraf dalam hierarki kebahasaan berada pada tataran yang tinggi. Artinya, penguasaan terhadap aspek kebahasaan di bawah hierarki paragraf/wacana seperti, struktur kalimat, kata, dan ejaan mutlak diperlukan.

Permasalahan-permasalahan di atas harus segera dicarikan solusinya. Salah satu solusi yang ditawarkan untuk meningkatkan kemampuan siswa dalam menulis paragraf adalah melalui pola latihan berjenjang. Hal ini sesuai dengan prinsip pembelajaran menulis yang dikemukakan oleh Parera $^{5}$ bahwa pembelajaran menulis itu berlangsung secara berjenjang. Pola latihan berjenjang adalah strategi pembelajaran menulis yang membelajarkan siswa untuk menulis secara bertahap dan bertingkat.

Strategi pemecahan masalah yang akan digunakan pada penelitian tindakan kelas ini adalah dengan menggunakan pola latihan berjenjang. Dengan pola ini, siswa akan berlatih menguasai tahapantahapan kebahasaan yang akan menunjang keberhasilannya dalam membuat paragaf persuasif. Pada tahap pertama, siswa disajikan paragraf gundul. Artinya, paragraf yang disajikan tidak dilengkapi dengan ejaan dan tidak ada batasan antara kalimat yang satu dengan yang lain. Secara kolaboratif siswa akan mengidentifikasi dan memperbaiki paragraf tersebut dengan memperhatikan ejaan dan satuan-satuan kalimat dengan benar. Kata-kata yang akan dilatihkan adalah kata-kata yang sering keliru ditulis oleh siswa pada proses pembelajaran sebelumnya. Pada tahap kedua, siswa akan berlatih menulis kalimat efektif secara kolaboratif dan 
menyusunnya menjadi paragraf. Pada tahap ketiga, siswa akan berlatih menulis paragraf persuasif sejumlah empat sampai enam kalimat secara individual.

Adapun tujuan khusus penelitian ini adalah untuk meningkatkan kemampuan siswa kelas X-4 SMA Negeri 1 Praya dalam menulis paragraf persuasif melalui pola latihan berjenjang.

\subsection{Menulis Paragraf Persuasif}

Menurut Kamus Besar Bahasa Indonesia ${ }^{6}$, menulis adalah melahirkan pikiran atau perasaan dengan tulisan, sedangkan menurut Tarigan $^{7}$, menulis merupakan suatu keterampilan berbahasa yang dipergunakan untuk berkomunikasi secara tidak langsung, tidak secara tatap muka dengan orang lain. The Liang $\mathrm{Gie}^{8}$ tidak membedakan arti menulis dengan mengarang. Mengarang adalah segenap rangkaian kegiatan seseorang mengungkapkan gagasan dan menyampaikannya melalui bahasa tulis kepada masyarakat pembaca untuk dipahami.

Dalam karang-mengarang diperlukan bahasa tulis sebagai medium untuk mengangkat gagasan dari pikiran seseorang kepada pihak pembaca. Setiap butir ide perlu dilekatkan pada suatu kata; katakata dirangkai menjadi ungkapan atau frasa; beberapa frasa digabung menjadi anak kalimat; sejumlah anak kalimat membangun sebuah kalimat; serangkaian kalimat membentuk alinea; alinea-alinea akhirnya mewujudkan sebuah karangan. Satuan-satuan dari penulisan sesuatu karangan adalah kalimat. Tetapi, satuan untuk pikiran dalam karangan adalah alinea. Seseorang pengarang berpikir dalam kerangka alinea, tetapi menuliskan gagasannya dalam susunan kalimat-kalimat.

Arifin dan Tasai $^{9}$ menjelaskan, paragraf adalah seperangkat kalimat yang membicarakan suatu gagasan atau topik. Kalimat-kalimat dalam paragraf memperlihatkan kesatuan pikiran atau mempunyai keterkaitan dalam membentuk gagasan atau topik tersebut. Sementara itu, menurut $\mathrm{Keraf}^{10}$, paragraf yang baik dan efektif harus memenuhi syarat-syarat sebagai berikut:

1. Kesatuan: yaitu semua kalimat yang membina alinea itu secara bersama-sama menyatakan suatu hal, suatu tema tertentu.

2. Koherensi: yaitu kekompakan hubungan antara sebuah kalimat dengan kalimat yang lain yang membentuk alinea itu.

3. Perkembangan alinea: yaitu penyusunan atau perincian gagasan-gagasan yang membina alinea itu. 
Karangan dapat digolongkan menurut bentuknya menjadi 4 yaitu: narasi (cerita), deskripsi (lukisan), eksposisi (paparan), dan argumentasi (bincangan). The Liang $\mathrm{Gie}^{11}$ dalam pengklasifikasian tersebut tidak ditemukan istilah persuasi. Dalam beberapa literatur bentuk argumentasi sering disamakan dengan bentuk persuasi. Tarigan ${ }^{12}$ mengatakan bila seorang pengarang mempergunakan nada mendebat (atau nada argumentatif) maka hasilnya adalah tulisan yang bersifat meyakinkan (atau tulisan persuasif). Tulisan persuasif adalah tulisan yang dapat merebut perhatian pembaca, yang dapat menarik minat, dan yang dapat meyakinkan mereka.

Artati $^{13}$ menyatakan bahwa paragraf persuasif adalah bentuk paragraf yang bertujuan untuk meyakinkan seseorang baik pembaca atau juga pendengar agar melakukan sesuatu yang dikehendaki penulis. Berdasarkan pengertian tersebut, dapat diketahui ciri-ciri paragraf persuasif:

1. Paragraf persuasif berusaha meyakinkan, mendorong, memengaruhi, membujuk seseorang atau pembaca.

2. Paragraf persuasif berusaha membuat pembaca tergerak untuk melakukan hal yang dikehendaki penulis.
3. Paragraf persuasif menggunakan fakta atau bukti untuk memengaruhi atau membujuk pembaca.

4. Paragraf persuasif menggunakan kalimat persuasif atau kalimat yang bersifat mengajak secara langsung atau tidak.

5. Paragraf persuasif menggunakan bahasa yang menarik dan bersifat sugesti.

Dari penjelasan di atas dapat dirumuskan struktur paragraf persuasif sebagai berikut:

\section{Gagasan/tesis-} pendukung/alasan/bukti/fakta ajakan

Agar gagasan yang akan disampaikan oleh penulis kepada pembaca tersampaikan dengan tepat, penulis harus menyusun paragrafnya dengan kalimatkalimat efektif. Kalimat efektif ialah kalimat yang memiliki kemampuan untuk menimbulkan kembali gagasan-gagasan pada pikiran pendengar atau pembaca seperti apa yang ada dalam pikiran pembicara atau penulis (Arifin dan Tasai $)^{14}$. Lebih lanjut dijelaskan, sebuah kalimat efektif mempunyai ciri-ciri khas, yaitu kesepadanan struktur, keparalelan bentuk, ketegasan makna, kehematan kata, kecermatan penalaran, kepaduan gagasan, dan kelogisan bahasa 


\subsection{Pola Latihan Berjenjang}

Dalam Kamus Besar Bahasa Indonesia $^{15}$ dijelaskan pola berarti sistem atau cara kerja; latihan/berlatih berarti belajar dan membiasakan diri agar mampu (dapat) melakukan sesuatu; jenjang berarti tingkatan-tingkatan yang beraturan dari bawah ke atas; berjenjang berarti mempunyai jenjang, bertingkat, bertahap. Dengan demikian, dapat disimpulkan bahwa pola latihan berjenjang bermakna suatu sistem belajar dan membiasakan diri agar mampu melakukan sesuatu dengan cara bertahap. Hal tersebut sejalan dengan salah satu prinsip umum belajar yaitu belajar berlangsung dari yang sederhana meningkat kepada yang kompleks (Sumiati dan Asra) ${ }^{16}$.

Lebih tegas lagi dijelaskan oleh Parera ${ }^{17}$ bahwa pembelajaran menulis itu berlangsung secara berjenjang. Pola latihan berjenjang adalah strategi pembelajaran menulis yang membelajarkan siswa menulis secara bertahap dan bertingkat.

Sementara itu, Tarigan ${ }^{18}$ mengatakan bahwa keterampilan itu erat berhubungan dengan dengan proses-proses yang mendasari bahasa. Bahasa seseorang mencerminkan pikirannya. Semakin terampil seseorang berbahasa semakin jelas dan cerah jalan pikirannya. Keterampilan hanya dapat diperoleh dan dikuasai dengan jalan praktik dan banyak latihan.

\section{Hasil dan Pembahasan}

\subsection{Tes Awal}

Untuk mengetahui kemampuan awal yang dimiliki oleh siswa dalam menulis paragraf persuasif, diberikan tes awal. Tes ini berfungsi untuk mendiagnosis kemampuan awal siswa sekaligus sebagai landasan untuk melihat peningkatan kemampuan siswa pada siklus I. Di samping itu, tes awal ini juga berfungsi untuk melihat letak kelemahan siswa dalam menulis paragraf, selanjutnya dianalisis dan direncanakan tindakan perbaikan yang akan dilakukan.

Hasil tes awal tersebut menunjukkan bahwa dari 34 orang siswa, $14,71 \%$ telah memiliki kemampuan menulis paragraf persuasif. Artinya, secara klasikal kemampuan siswa masih rendah. Rendahnya kemampuan siswa tersebut dapat dilihat dari kemampuannya menguasai kompleksitas (ejaan, tanda baca, dan penulisan kata) dengan ratarata 1,44 ; rata-rata penguasaan struktur kalimat 1,68; kesesuaian dengan syarat paragraf yang baik 1,88; dan kesesuaian dengan karakteristik paragraf persuasif 1,62 . 
Mencermati rendahnya kemampuan siswa tersebut, perlu dilaksanakan tindakan selanjutnya.

\subsection{Siklus I}

Sebagaimana telah dijelaskan di atas, setiap siklus terdiri atas perencanaan, pelaksanaan tindakan, observasi, dan refleksi. Kegiatan perencanaan dimulai dengan mempersiapkan skenario pembelajaran dengan menerapkan pola latihan berjenjang. Pada jenjang pertama, siswa diberikan LKS yang berisi paragraf persuasif gundul. Artinya, paragraf tersebut tidak dilengkapi dengan ejaan, tanda baca, huruf kapital, dan batas-batas satuan kalimat. Selanjutnya, siswa secara berkelompok memperbaiki paragraf tersebut sehingga menjadi paragraf persuasif yang baik. Setelah itu, siswa mengidentifikasi karakteristik paragraf persuasif. Pada jenjang kedua, siswa membuat kerangka paragraf dan menyusunnya menjadi paragraf secara kolaboratif. Pada jenjang ketiga, secara individual, siswa membuat paragraf persuasif dengan beberapa pilihan tema yang telah disiapkan.

Setelah tindakan

dilaksanakan, sebanyak 21 orang siswa memenuhi kriteria ketuntasan. Berdasarkan hasil belajar tersebut disimpulkan bahwa $61,76 \%$ siswa telah memiliki kemampuan menulis paragraf persuasif. Artinya, secara klasikal kemampuan siswa mengalami peningkatan yang signifikan tetapi belum mencapai indikator keberhasilan yang telah ditetapkan (80\%). Peningkatan kemampuan siswa tersebut dapat dilihat dari kemampuan siswa menguasai kompleksitas (ejaan, tanda baca, dan penulisan kata) dengan ratarata 2,29; rata-rata penguasaan struktur kalimat 2,35; kesesuaian dengan syarat paragraf yang baik 2,53; dan kesesuaian dengan karakteristik paragraf persuasif 2,82 .

\subsection{Siklus II}

Dari data hasil belajar dan observasi didapatkan beberapa kelemahan pada siklus I. Dari jurnal guru model diketahui, siswa mengalami kesulitan pada saat mengerjakan soal yang terdapat pada LKS 1 Jenjang pertama. Hal tersebut disebabkan oleh terbatasnya jumlah LKS yang dibagikan ke setiap kelompok (1 LKS $=1$ kelompok). Di samping itu, analisis terhadap alokasi waktu untuk setiap jenjang kurang akurat sehingga proses ini berakhir melebihi waktu yang telah ditetapkan yaitu 2 x 45 menit.

Selain kekurangan di atas, dari lembar observasi juga diketahui, guru model tidak mengecek kehadiran siswa. Tidak dibahasnya hasil kerja kelompok 
pada jenjang kedua, juga merupakan kekurangan pada siklus ini. Pembahasan ini penting untuk mengetahui tingkat keberhasilan siswa pada soal LKS 2. Di samping itu, disarankan agar hasil kerja kelompok yang telah dikoreksi ditempelkan di tembok kelas.

Berdasarkan kelemahankelemahan tersebut, disusunlah perencanaan siklus II. Setelah dilaksanakan, jumlah siswa yang memenuhi kriteria meningkat menjadi 30 orang. Dari hasil belajar tersebut disimpulkan bahwa $88,24 \%$ siswa telah memiliki kemampuan menulis paragraf persuasif. Artinya, secara klasikal kemampuan siswa mengalami peningkatan dan telah mencapai bahkan melampaui indikator keberhasilan yang telah ditetapkan (80\%). Peningkatan kemampuan siswa tersebut dapat dilihat dari kemampuan siswa menguasai kompleksitas (ejaan, tanda baca, dan penulisan kata) dengan ratarata 2,47 ; rata-rata penguasaan struktur kalimat 2,65; kesesuaian dengan syarat paragraf yang baik 2,74; dan kesesuaian dengan karakteristik paragraf persuasif 2,71 .

\subsection{Siklus III}

$\begin{array}{cr}\text { Untuk } & \text { memperkuat } \\ \text { pemahaman siswa terhadap }\end{array}$ paragraf persuasif, pada siklus III siswa diberikan soal yang lebih kompleks berupa karangan persuasif. Artinya, siswa akan membuat sebuah karangan persuasif yang terdiri atas beberapa paragraf. Hal ini bertujuan untuk melihat kerangka berpikir siswa secara lebih luas dalam menyampaikan gagasannya.

Setelah perencanaan dibuat dan dilaksanakan tindakan, diperoleh hasil 31 orang siswa $(91,18 \%)$ memenuhi kriteria ketuntasan. Meskipun indikator keberhasilan menunjukkan peningkatan, ada catatan untuk siklus III ini yaitu terjadi penurunan skor pada unsur kompleksitas dan kesesuaian terhadap karakteristik/organisasi karangan persuasif. Hal ini terjadi karena tugas yang dikerjakan siswa lebih kompleks.

Perkembangan hasil belajar siswa mulai dari tes awal sampai siklus III dapat dilihat pada tabel berikut ini. 


\begin{tabular}{|c|l|c|c|c|c|c|}
\hline No & Tahap & Jumlah Siswa & Tuntas & $\%$ & Tdk. Tuntas & $\%$ \\
\hline 1 & Tes Awal & 34 orang & 5 & 14,71 & 29 & 85,29 \\
\hline 2 & Siklus I & 34 orang & 21 & 61,76 & 13 & 38,24 \\
\hline 3 & Siklus II & 34 orang & 30 & 88,24 & 4 & 11,76 \\
\hline 4 & Siklus III & 34 orang & 31 & 91,18 & 3 & 8,82 \\
\hline
\end{tabular}

Selanjutnya, data perkembangan skor pada setiap unsur penilaian dapat dilihat pada tabel berikut ini

\begin{tabular}{|c|c|c|c|c|c|c|c|c|c|c|}
\hline \multirow{3}{*}{ No } & \multirow{3}{*}{ Tahap } & \multirow{3}{*}{$\begin{array}{c}\text { Skor Maks. } \\
\text { x jum. } \\
\text { siswa }\end{array}$} & \multicolumn{8}{|c|}{ Perkembangan Skor Setiap Unsur Penilaian } \\
\hline & & & \multicolumn{2}{|c|}{ Unsur 1} & \multicolumn{2}{|c|}{ Unsur 2} & \multicolumn{2}{|c|}{ Unsur 3} & \multicolumn{2}{|c|}{ Unsur 4} \\
\hline & & & Jum. & $\%$ & Jum. & $\%$ & Jum. & $\%$ & Jum. & $\%$ \\
\hline 1 & Tes Awal & 102 & 49 & 48,04 & 57 & 55,88 & 64 & 62,75 & 55 & 53,92 \\
\hline 2 & Siklus I & 102 & 78 & 76,47 & 80 & 78,43 & 86 & 84,31 & 96 & 94,12 \\
\hline 3 & Siklus II & 102 & 84 & 82,34 & 90 & 88,74 & 93 & 91,18 & 92 & 90,20 \\
\hline 4 & Siklus III & 102 & 77 & 75,49 & 95 & 93,14 & 91 & 89,22 & 96 & 94,12 \\
\hline
\end{tabular}

\section{Keterangan}

Unsur 1 : kompleksitas (ketepatan penggunaan ejaan dan diksi)

Unsur 2 : struktur kalimat

Unsur 3 : kesesuaian dengan syarat paragraf yang baik

Unsur 4 : kesesuaian dengan karakteristik paragraf/karangan persuasif

\section{Simpulan dan Saran}

\subsection{Simpulan}

Dari pelaksanaan tindakan dapat ditarik simpulan bahwa pola latihan berjenjang dapat meningkatkan kemampuan menulis paragraf persuasif bagi siswa kelas X-4 SMA Negeri 1 Praya. Di samping itu, pola latihan berjenjang ini juga mampu meningkatkan kualitas proses belajar mengajar.

\subsection{Saran}

Melihat hasil positif dari penerapan pola latihan berjenjang ini disarankan agar pola ini diterapkan juga pada kompetensikompetensi dasar menulis lainnya seperti argumentasi, eksposisi, narasi, dan deskripsi. Di samping itu, penerapan pola ini agar lebih ditingkat sampai pada tataran wacana. 


\section{DAFTAR PUSTAKA}

${ }^{1}$ Permendiknas Nomor 22 Tahun 2006 tentang Standar Isi

${ }^{2}$ Tarigan, Henry Guntur. 1992. Menulis sebagai Suatu Keterampilan Berbahasa. Bandung: Angkasa

${ }^{3}$ Tarigan, Henry Guntur. 1992. Menulis sebagai Suatu Keterampilan Berbahasa. Bandung: Angkasa

${ }^{4}$ Tarigan, Djago dan Henry Guntur Tarigan. 1987. Teknik Pengajaran Keterampilan Berbahasa. Bandung: Angkasa

${ }^{5}$ Parera, Jos Daniel. 1996. Pedoman Kegiatan Belajar Mengajar, Landas Pikir Landas Teori. Jakarta: Grasindo

${ }^{6}$ Departemen Pendidikan Nasional. 2001. Kamus Besar Bahasa Indonesia Edisi Ketiga. Jakarta: Balai Pustaka

${ }^{7}$ Tarigan, Henry Guntur. 1992. Menulis sebagai Suatu Keterampilan Berbahasa. Bandung: Angkasa

${ }^{8}$ Gie, The Liang. 2002. Terampil Mengarang. Yogyakarta: Andi

${ }^{9}$ Arifin, E. Zaenal dan S.Amran Tasai. 1999. Cermat Berbahasa Indonesia untuk Perguruan Tinggi. Jakarta: Akademika Pressindo

${ }^{10}$ Keraf, Gorys. 1984. Komposisi. Ende-Flores: Nusa Indah

${ }^{11}$ Gie, The Liang. 2002. Terampil Mengarang. Yogyakarta: Andi

${ }^{12}$ Tarigan, Henry Guntur. 1992. Menulis sebagai Suatu Keterampilan Berbahasa. Bandung: Angkasa

${ }^{13}$ Artati, Y. Budi. 2012. Bahasa Indonesia untuk SMA/MA Kelas X Semester 2 (PG). Klaten: Intan Pariwara

${ }^{14}$ Arifin, E. Zaenal dan S.Amran Tasai. 1999. Cermat Berbahasa Indonesia untuk Perguruan Tinggi. Jakarta: Akademika Pressindo

${ }^{15}$ Departemen Pendidikan Nasional. 2001. Kamus Besar Bahasa Indonesia Edisi Ketiga. Jakarta: Balai Pustaka

${ }^{16}$ Sumiati dan Asra. 2007. Metode Pembelajaran. Bandung : CV Wacana Prima.

${ }^{17}$ Parera, Jos Daniel. 1996. Pedoman Kegiatan Belajar Mengajar, Landas Pikir Landas Teori. Jakarta: Grasindo

${ }^{18}$ Tarigan, Henry Guntur. 1992. Menulis sebagai Suatu Keterampilan Berbahasa. Bandung: Angkasa 